\title{
HUBUNGAN PENGETAHUAN DENGAN SIKAP DALAM PEMBERIAN IMUNISASI DASAR LENGKAP PADA IBU YANG MEMILIKI BAYI 0-9 BULAN DI PUSKESMAS ALIANYANG TAHUN 2016
}

\section{Chahyani Erlita $^{1}$, Elise Putri ${ }^{2}$}

Akademi Kebidanan Panca Bhakti Pontianak

Email korespondensi: akbidpbpontianak@gmail.com

\begin{abstract}
Abstrak
Imunisasi adalah upaya untuk meningkatkan kekebalan tubuh seseorang secara aktif terhadap suatu penyakit. Data yang diperoleh menunjukan bahwa cakupan Universal Child Imunization (UCI) di Kalimantan Barat menduduki posisi ke empat terendah di Indonesia. Data cakupan imunisasi dasar lengkap di Kota Pontianak sebesar 55\% dari total target 95\%. Tujuan dalam penelitian ini adalah peneliti ingin mengetahui tingkat pengetahuan responden tentang imunisasi dasar lengkap, sikap responden dalam pemberian imunisasi dasar lengkap dan hubungan pengetahuan dan sikap ibu dalam pemberian imunisasi dasar lengkap di Puskesmas Alianyang. Desain penelitian dalam penelitian ini adalah penelitian deskriptif korelasi dengan pendekatan cross sectional. Populasi dari penelitian ini adalah ibu yang memiliki bayi usia 0-9 bulan yaitu sejumlah 306 orang. Sampel dari penelitian ini adalah 31 orang dengan teknik sampel menggunakan teknik accidental. Sumber data menggunakan kuesioner. Berdasarkan hasil penelitian diperoleh hasil sebagian responden memiliki pengetahuan "cukup" dan sikap responden sebagian besar termasuk dalam kategori "mendukung". Uji chi square menunjukan $\mathrm{X}^{2}$ 0,370 dan nilai $\mathrm{P}$ value $=1,991$ maka Kesimpulkan dari penelitian ini adalah tidak ada hubungan pengetahuan dengan sikap ibu dalam pemberian imunisasi dasar lengkap. Saran untuk tempat penelitian adalah agar dapat melaksanakan kegiatan pendidikan kesehatan secara rutin khususnya mengenai imunisasi dasar lengkap agar dapat meningkatkan pengetahuan tentang imunisasi dasar lengkap sehingga dapat ikut mendukung program pemerintah mengenai imunisasi dasar lengkap yang wajib diberikan pada semua anak.
\end{abstract}

Kata Kunci: Pengetahuan, Sikap, Imunisasi

\section{Pendahuluan}

Angka status kesehatan merupakan salah satu indikator keberhasilan suatu negara. Semakin maju suatu negara maka semakin rendah angka kesakitan pada negara tersebut. Di Indonesia telah banyak program pemerintah yang berkaitan dalam upaya peningkatan kesehatan, khususnya untuk ibu dan anak yang diharapkan dapat menurunkan angka kesakitan pada ibu dan anak.

\section{Hasil Survey Demografi Kesehatan} Indonesia (SDKI) tahun 2012 menunjukkan bahwa kematian anak selama lima tahun adalah 32 kematian per 1.000 kelahiran hidup. Artinya, setiap 1 hari dari 31 anak yang lahir di Indonesia

\footnotetext{
${ }^{1}$ Dosen Akademi Kebidanan Panca Bhakti Pontianak
}

${ }^{2}$ Dosen Akademi Kebidanan Panca Bhakti Pontianak meninggal sebelum mencapai umur 1 tahun, $60 \%$ bayi mati terjadi pada umur 1 bulan, angka kematian neonatus sebesar 19 kematian per 1.000 kelahiran hidup, $80 \%$ anak meninggal terjadi saat berumur 1-11 bulan, angka kematian post neonatorum sebesar 13 kematian per 100.000 kelahiran hidup. Angka kematian balita dan anak masing-masing sebesar 40 dan 9 kematian per 1.000 kelahiran hidup. Angka kematian anak adalah sekitar sepertiga dari angka kematian bayi, 9 berbanding 32 kematian per 1.000 kelahiran hidup (Survey Demografi Kesehatan Indonesia, 2012). 
Anak adalah anugerah Tuhan Yang Maha

Esa, kehadirannya merupakan dambaan bagi setiap pasangan suami istri yang telah menikah. Anak adalah generasi penerus bangsa, untuk menghasilkan generasi penerus bangsa yang sehat, tentunya anak harus dibekalkan sistem imun yang baik agar anak tidak dengan mudah terserang berbagai macam penyakit dikemudian hari Indonesia adalah negara dengan jumlah penduduk sebanyak 246.864 juta jiwa ditahun 2012 dengan 72.329 juta penduduknya berusia dibawah 15 tahun. Angka kematian bayi dan balita di Indonesia masih cukup tinggi, yaitu 25 bayi berusia dibawah 12 bulan per 1.000 kelahiran hidup pertahun dan 32 balita berusia dibawah 5 tahun per 1.000 kelahiran hidup pertahun.

Mayoritas kematian anak dibawah satu tahun di Indonesia disebabkan infeksi saluran nafas akut, komplikasi perinatal yang terjadi pada bayi berusia 0-28 hari, yang sebagian masih berkaitan dengan proses persalinan dan diare. Sebagian penyakit-penyakit infeksi penyebab kematian bayi dan balita ini dapat dicegah dengan imunisasi, seperti campak, vaksin pertusis, vaksin Hib, vaksin pneumokokus, dan vaksin rotavirus. Inilah sebabnya imunisasi menjadi hal yang sangat penting untuk dilaksanakan di Indonesia dan harus mempunyai angka cakupan tinggi (Arifianto, 2014).

Upaya yang telah dilakukan selama ini untuk menurunkan Angka Kematian Balita $(\mathrm{AKBa})$ berhasil menunjukan perbaikan yang sangat berarti antara 1960 dan 1990. Rata-rata penurunan Angka Kematian Balita (AKBa) pada dekade 1990-an adalah $7 \%$ per tahun lebih tinggi dari dekade sebelumnya yaitu $4 \%$ per tahun (Lisnawati, 2014).

Berdasarkan Peraturan Menteri Kesehatan RI nomor 42 tahun 2013 tentang penyelenggaraan imunisasi pasal 1 ayat 1 imunisasi adalah suatu upaya untuk menimbulkan atau meningkatkan kekebalan seseorang secara aktif terhadap suatu penyakit, sehingga bila suatu saat terserang dengan penyakit tersebut tidak akan sakit atau hanya mengalami sakit ringan. Imunisasi merupakan hal wajib yang diberikan pada setiap anak yang lahir, sebagaimana yang tercantum dalam Undang-Undang No. 36 Tahun 2009 Pasal 130 yang berisi pemerintah wajib memberikan imunisasi lengkap kepada setiap bayi dan anak (Departemen Kesehatan Republik Indonesia, 2014).

Kekebalan (imunitas) terhadap penyakit infeksi terbentuk akibat respons (reaksi) tubuhnya terhadap mikroorganisme penyebab penyakit. Sistem kekebalan tubuh mengenal mikroorganisme seperti bakteri, virus, jamur, dan parasit yang disebut antigen. Mekanisme sistem imun tubuh sangat kompleks, yang terdiri atas kumpulan organ, jaringan, sel, dan molekul. Kenyataannya, tubuh kita telah dianugerahi oleh yang Maha Kuasa dua jalur pertahanan yang saling berhubungan, yang melindungi kita dari serangan mikroorganisme yang berbahaya (mikroorganisme patogen). Kedua imunitas tersebut adalah imunitas lahiriah (imunitas non spesifik) dan imunitas yang didapat setelah lahir 
(imunitas spesifik) (Ikatan Dokter Anak Indonesia, 2011).

Program imunisasi dilaksanakan di Indonesia sejak tahun 1956. Menurut Keputusan Menteri Kesehatan Republik Indonesia Nomor 1611/MENKES/SK/XI/2005, program pengembangan imunisasi mencakup satu kali HB-0, satu kali imunisasi BCG, tiga kali imunisasi DPT-HB, empat kali imunisasi polio, dan satu kali imunisasi campak. Hasil Riset Kesehatan Dasar (RISKESDAS) 2013 didapatkan cakupan imunisasi lengkap pada anak umur 12-23 bulan. Cakupan imunisasi lengkap di Indonesia cenderung meningkat dari tahun 2007 (41,6\%), $2010(53,8 \%)$, dan 2013 (59,2 \%). Sedangkan cakupan imunisasi tidak lengkap tahun 2007 (49,2 \%), 2010 (33,5\%), dan 2013 (32,1\%). Dan yang tidak diimunisasi pada tahun 2007 (9,1\%), 2010 (12,7\%), dan 2013 (8,7\%) (Riset Kesehatan Dasar, 2013).

Survey Demografi Kesehatan Indonesia (SDKI) 2012 menggumpulkan informasi tentang cakupan imunisasi yang memperlihatkan presentase anak umur 12-23 bulan, hasil menunjukan secara keseluruhan $60 \%$ dari anak umur 12-23 bulan telah mendapatkan imunisasi lengkap, tidak termasuk $\mathrm{Hb} O$, sementara $37 \%$ mendapat imunisasi lengkap dengan $\mathrm{Hb} \quad \mathrm{O}$. Persentase cakupan pemberian imunisasi lengkap oleh ibu dengan tingkat pendidikan perguruan tinggi mencapai 70,0 \%, tamat SMTA 69,4\%, tidak tamat SMTA 69,8\%, tamat SD 65,3\%, tidak tamat SD 38,1 \%, dan tidak sekolah 19,4\% (Survey Demografi Kesehatan Indonesia, 2012).
Pengetahuan adalah hasil penginderaan manusia, atau hasil tahu seseorang terhadap objek melalui indera yang dimilikinya (mata, hidung, telinga, dan sebagainya). Dalam penelitian ini peneliti ingin mengetahui sejauh mana pengetahuan mempengaruhi sikap ibu yang memiliki bayi 0-9 bulan dalam pemberian imunisasi dasar lengkap.

Berdasarkan Data dan Informasi Kesehatan Provinsi Kalimantan Barat tahun 2014 sumber data Ditjen PPPL, Kementerian Kesehatan Republik Indonesia, 2014 tercatat persentase imunisasi dasar lengkap pada bayi di Indonesia per September 2014 adalah 48,4 \%, khususnya di Kalimantan Barat sebesar 44,7 \% dan di Kota Pontianak 55,0 \% (Dinas Kesehatan Kalimantan Barat, 2014).

Program imunisasi dasar, Lima Imunisasi dasar Lengkap (LIL), yang dicanangkan oleh pemerintah bagi bayi meliputi 1 dosis BCG, 3 dosis DPT, 4 dosis Polio, 4 dosis Hepatitis $B$ dan 1 dosis Campak (Depkes, 2010). Namun pada kenyataannya program imunisasi dasar lengkap yang telah dilakukan tidak seluruhnya berhasil dan masih banyak bayi atau balita status kelengkapan imunisasinya belum lengkap, banyak faktor yang menyebabkan kelengkapan imunisasi, faktor tersebut antara lain sikap petugas, lokasi imunisasi, kehadiran petugas, usia ibu, tingkat pendidikan ibu, tingkat pendapatan keluarga per bulan, kepercayaan terhadap dampak buruk pemberian imunisasi, status pekerjaan ibu, tradisi keluarga, tingkat pengetahuan ibu, dan dukungan keluarga (Rahmawati, 2014). 
Sikap adalah respon tertutup seseorang terhadap stimulus atau objek tertentu, yang sudah melibatkan faktor pendapat dan emosi yang bersangkutan (senang-tidak senang, setuju-tidak setuju, baik-tidak baik, dan sebagainya). Dalam penelitian ini peneliti ingin mengetahui apakah sikap ibu dalam pemberian imunisasi dasar pada bayinya sudah sesuai dengan pengetahuan yang dimilikinya.

Dari penelitian yang dilakukan oleh Lilis dan kawan-kawan mahasiswa Program Studi S1 Keperawatan, Universitas Respati Yogyakarta dengan judul Hubungan Pengetahuan Ibu Tentang Imunisasi Dasar Dengan Kelengkapan Imunisasi Dasar Pada Bayi Usia 1 Tahun Di Puskesmas Depok I Sleman Yogyakarta dari Hasil penelitian diketahui tingkat pengetahuan ibu tentang imunisasi dasar di Puskesmas Depok I Sleman Yogyakarta sebagian besar dalam kategori baik sebesar 77,5\%. Kelengkapan imunisasi dasar pada bayi di Puskesmas Depok I Sleman Yogyakarta sebesar $85 \%$. Berdasarkan uji chi square diperoleh kesimpulan bahwa ada hubungan pengetahuan ibu tentang imunisasi dasar dengan kelengkapan imunisasi dasar pada bayi usia 1 tahun di Puskesmas Depok I Sleman Yogyakarta.

Hal ini sesuai dengan hasil penelitian yang telah dilakukan oleh Siti Umaroh mahasiswi Program Studi Kesehatan Masyarakat, Universitas Muhammadiyah Surakarta dengan judul Hubungan Antara Pengetahuan dan Sikap Ibu Dengan Kelengkapan Imunisasi Dasar di Wilayah Kerja Puskesmas Kartasura Kabupaten
Sukoharjo diketahui bahwa anak yang mempunyai status imunisasi lengkap (kontrol) sebagian besar mempunyai ibu dengan tingkat pengetahuan baik sebanyak 29 responden dan anak yang mempunyai status imunisasi lengkap (kontrol) sebagian besar mempunyai ibu dengan sikap positif sebanyak 26 responden. Berdasarkan hasil yang didapat dengan uji chi square menunjukkan bahwa ada hubungan antara pengetahuan dan sikap ibu dengan kelengkapan imunisasi dasar.

Sedangkan menurut Ejurnal Sekolah Tinggi Ilmu Kesehatan Prima Nusantara Volume 1 No 1 oleh Selvina Elia Roza mahasiswi Diploma III kebidanan Sekolah Tinggi Ilmu Kesehatan Prima Nusantara Bukit Tinggi dengan judul Hubungan Pengetahuan Dan Sikap Ibu Balita Dengan Cakupan Imunisasi Campak di Kelurahan Aur Kuning Wilayah Kerja Puskesmas Tigo Baleh Tahun 2013 dimana dari hasil penelitian yang telah dilakukan diperoleh sebagian dari responden memiliki pengetahuan dalam kategori "rendah" (54,5\%) sedangkan ada sebagian dari responden yang memiliki sikap dalam kategori "negatif" (51,9\%).

Dari data yang diperoleh menunjukan bahwa cakupan Universal Child Imunization (UCI) di Kalimantan Barat menduduki posisi ke empat terendah di Indonesia. Sedangkan data cakupan imunisasi dasar lengkap di Kota Pontianak hanya sebesar $55 \%$ dari total target 95\% di Indonesia. Berdasarkan sumber data Profil Kesehatan Kota Pontianak, pada tahun 2014 telah terjadi kasus kematian anak di Puskesmas 
Alianyang sejumlah 2 neonatus, 2 anak, dan 2 balita. Pada penelitian ini peneliti ingin mengetahui apakah ada hubungan antara tingkat pengetahuan ibu yang memiliki bayi

usia 0-9 bulan di Puskesmas Aliayang terhadap sikap dalam pemberian imunisasi pada bayinya.

\section{Metode}

Penelitian ini menggunakan jenis penelitian deskriptif korelasional dengan pendekatan cross sectional. Penelitian dilaksanakan pada bulan Januari hingga Mei 2016 di Puskesmas Alianyang Kota Pontianak Provinsi Kalimantan Barat. Populasi penelitian yaitu seluruh ibu yang memiliki bayi 0-9 bulan pada bulan Januari hingga Maret 2016 sebanyak 306 orang. Peneliti menggunakan $10 \%$ jumlah populasi sebanyak 31 orang. Pengumpulan data menggunakan kuesioner kemudian diolah dan dianalisis menggunakan analisis univariat serta analisis bivariat menggunakan uji chi square.

\section{Hasil dan Pembahasan}

\begin{tabular}{lcc}
\multicolumn{3}{c}{ Tabel 1: Karakteristik Responden } \\
\hline \multicolumn{1}{c}{ Karakteristik } & $\mathrm{n}$ & $\%$ \\
\hline Pengetahuan & 2 & 6,45 \\
$\quad$ Kurang & 18 & 58,07 \\
Cukup & 11 & 35,48 \\
Baik & & \\
Sikap & 19 & 61,30 \\
$\quad$ Mendukung & 12 & 38,70 \\
$\quad$ Tidak Mendukung &
\end{tabular}

Berdasarkan tabel 1 diketahui bahwa sebagian responden yaitu sejumlah 18 orang $(58,07 \%)$ memiliki pengetahuan termasuk dalam kategori "cukup" tentang imunisasi dasar lengkap dan sangat sedikit dari responden yaitu sejumlah 2 orang $(6,45 \%)$ memiliki pengetahuan termasuk dalam kategori "kurang” tentang imunisasi dasar lengkap. Tabel 1 menunjukkan bahwa sebagian besar responden yaitu sejumlah 19 orang $(61,30 \%)$ memiliki sikap yang termasuk dalam kategori "mendukung".

Tabel 2. Analisis Bivariat

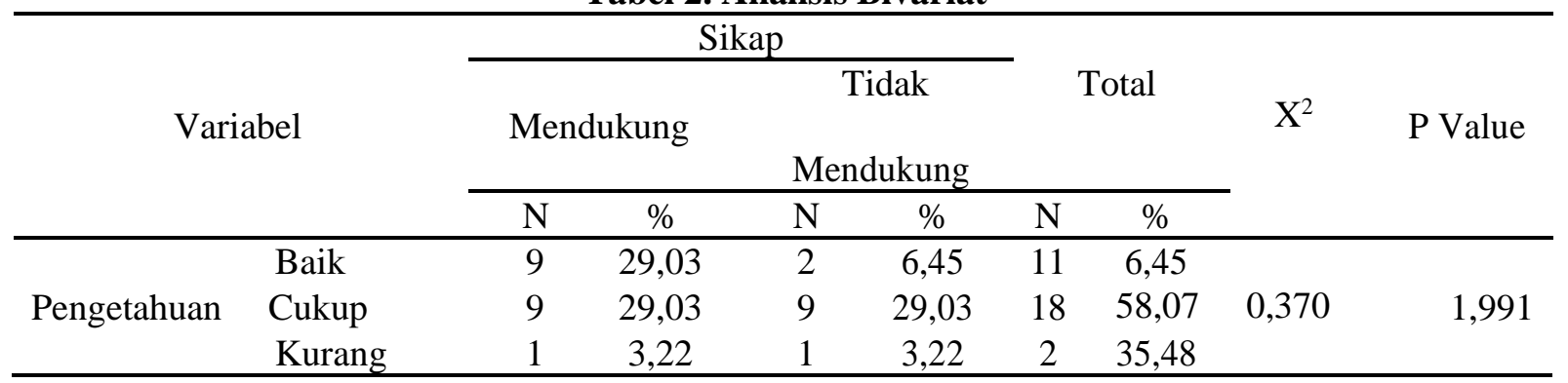


Dari hasil penelitian yang telah dilakukan terhadap 31 responden menunjukan bahwa pengetahuan responden mengenai imunisasi dasar lengkap sebagian dari responden dikategorikan "cukup" yaitu berjumlah 18 orang $(58,07 \%)$, kemudian sebagian kecil responden termasuk kategori "baik" dengan jumlah 11 orang $(35,48 \%)$ dan sangat sedikit dari responden termasuk kategori "kurang" yang berjumah 2 orang $(6,45 \%)$.

Menurut Mubarak (2007) bahwa semakin tinggi pendidikan seseorang maka semakin mudah pula mereka menerima informasi dan pada akhirnya makin banyak pula pengetahuan yang dimilikinya. Sebaliknya jika seseorang tingkat pendidikannya rendah akan menghambat perkembangan sikap seseorang terhadap penerimaan, informasi dan nilai-nilai yang baru diperkenalkan.

Hal ini sesuai dengan hasil penelitian yang telah dilakukan oleh Anis Zakiyah mahasiswi Universitas Muhammadiyah Semarang pada tahun 2010 dengan judul Hubungan Pengetahuan, Sikap Ibu Tentang Imunisasi dan Dukungan Keluarga Dengan Kelengkapan Imunisasi DPT Pada Bayi Umur 6-11 Bulan Di Desa Taman Gede Kecamatan Gemuh Kabupaten Kendal, menunjukan bahwa sebagian besar responden yaitu $78,7 \%$ memiliki pengetahuan dalam kategori "baik".

Namun bertolak belakang dengan Ejurnal STIKes Prima Nusantara Volume 1 No 1 oleh Selvina Elia Roza mahasiswi Diploma III kebidanan Sekolah Tinggi Ilmu Kesehatan Prima
Nusantara Bukit Tinggi dengan judul Hubungan Pengetahuan dan Sikap Ibu Balita Dengan Cakupan Imunisasi Campak di Kelurahan Aur Kuning Wilayah Kerja Puskesmas Tigo Baleh Tahun 2013 yang menyatakan sebagian responden memiliki pengetahuan dalam kategori "rendah" (54,5\%) sedangkan ada sebagian responden yang memiliki sikap dalam kategori “negatif” (51,9\%).

Dalam penelitian ini pengetahuan responden tentang imunisasi dasar lengkap dapat dikatakan sudah memadai dilihat dari jumlah responden yang memiliki pengetahuan yang kurang hanya terdapat 2 orang saja dan selebihnya memiliki pengetahuan yang baik dan cukup yang menunjukkan kesesuaian dengan teori Mubarak (2007) semakin tinggi tingkat pengetahuan maka semakin banyak pengetahuan yang dimilikinya.

Dari hasil penelitian yang telah dilakukan terhadap 31 responden menunjukkan bahwa sebagian besar responden yaitu berjumlah 19 orang $(61,30 \%)$ memiliki sikap yang termasuk dalam kategori "mendukung" dalam pemberian imunisasi dasar lengkap dan sebagian kecil responden yaitu sebesar 12 orang $(38,70 \%)$ memiliki sikap yang termasuk dalam kategori "tidak mendukung" dalam pemberian imunisasi dasar lengkap.

Pada penelitian ini menunjukkan kesesuaian dengan teori Newcomb yang menyatakan bahwa semakin baik sikap seseorang maka seseorang itu dapat menerima stimulus yang diberikan, memberi jawaban atas pertanyaan, memberikan nilai yang positif, dan 
mampu bertanggung jawab atas apa yang diyakininya (Notoatmodjo, 2010).

Hal ini menunjukkan bahwa terdapat kesamaan dengan hasil penelitian yang telah dilakukan oleh oleh Siti Umaroh mahasiswi Program Studi Kesehatan Masyarakat, Universitas Muhammadiyah Surakarta dengan judul Hubungan Antara Pengetahuan dan Sikap Ibu Dengan Kelengkapan Imunisasi Dasar Di Wilayah Kerja Puskesmas Kartasura Kabupaten Sukoharjo diketahui bahwa sebagian besar responden mempunyai sikap positif $(74,3 \%)$ terhadap imunisasi.

Hal ini menunjukkan bahwa sikap responden terhadap pemberian imunisasi dasar lengkap sebagian besar menunjukkan sikap yang "mendukung", sesuai dengan teori Newcomb yang menyatakan bahwa semakin baik sikap seseorang maka mampu memberikan nilai yang positif, dan mampu bertanggung jawab atas apa yang diyakininya.

Dari penelitian yang telah dilakukan menunjukkan bahwa sebagian kecil dari responden yaitu sejumlah 9 orang $(29,03 \%)$ berpengetahuan "cukup" dan menunjukan sikap yang "mendukung" dalam pemberian imunisasi dasar lengkap. Dan sebagian kecil dari responden yaitu sejumlah 9 orang $(29,03 \%)$ berpengetahuan "cukup" dan menunjukan sikap yang "tidak mendukung" dalam pemberian imunisasi dasar lengkap. Sedangkan sangat sedikit dari responden yaitu sejumlah 1 orang $(3,22 \%)$ berpengetahuan "kurang" dan menunjukan sikap yang "mendukung" dalam imunisasi dasar lengkap.
Dan sangat sedikit dari responden yaitu sejumlah 1 orang $(3,22 \%)$ berpengetahuan "kurang" dan menunjukan sikap yang "tidak mendukung".

Dari analisis bivariat yang telah dilakukan, didapatkan hasil $\mathrm{X}^{2}$ 0,370 dan $\mathrm{P}$ value $=1,991$ sehingga dapat diketahui bahwa "Tidak ada hubungan antara pengetahuan dan sikap ibu dalam pemberian imunisasi dasar lengkap pada ibu yang memiliki bayi 0-9 bulan".

Menurut Notoatmodjo, 2010 Semakin tinggi pengetahuan seseorang, maka seseorang itu dapat lebih banyak mengetahui tentang suatu hal tersebut dan mampu menginterpretasikan, mengaplikasikan, menjabarkan, merangkum dan melakukan penilaian terhadap suatu objek tertentu.

Hal ini sejalan dengan Jurnal Ilmiah Universitas Tanjungpura oleh Anggraeni Puspita Rati mahasiswi Program Studi Keperawatan Fakultas Kedokteran Universitas Tanjungpura Pontianak dengan judul Analisis Faktor-Faktor Yang Mempengaruhi Kelengkapan Imunisasi Dasar Lengkap Pada Batita Usia 9-24 Bulan Di Desa Pal IX Kecamatan Sungai Kakap Kabupaten Kubu Raya diperoleh dari hasil uji statistik yang digunakan yaitu uji chi square dengan nilai kemaknaan $\mathrm{p} \leq 0,05$ didapatkan nilai $\mathrm{p}$ sebesar 0,509 ( $p>0,05)$, maka artinya tidak ada hubungan yang bermakna antara pengetahuan ibu dengan kelengkapan imunisasi dasar batita usia 9-24 bulan di Desa Pal IX Kecamatan Sungai Kakap Kabupaten Kubu Raya tahun 2015.

Walaupun secara statistik menunjukkan bahwa tidak ada hubungan antara pengetahuan 
dan sikap ibu dalam pemberian imunisasi dasar lengkap pada ibu yang memiliki bayi usia 0-9 bulan di Puskesmas Alianyang tahun 2016. Akan tetapi data menunjukkan bahwa ibu yang berpengetahuan baik cenderung mendukung pemberian imunisasi dasar lengkap, hal ini terbukti dari data tabel 4.3 dimana ibu yang memiliki pengetahuan baik ada 9 orang yang memiliki sikap mendukung dalam pemberian imunisasi dasar lengkap pada bayi usia 0-9 bulan. Demikian juga pada hasil penelitian yang telah dilakukan oleh Siti Umaroh mahasiswi Program Studi Kesehatan Masyarakat, Universitas Muhammadiyah Surakarta dengan judul Hubungan Antara Pengetahuan dan Sikap Ibu Dengan Kelengkapan Imunisasi Dasar di Wilayah Kerja Puskesmas Kartasura Kabupaten Sukoharjo diketahui pengetahuan responden di wilayah kerja Puskesmas Kartasura Kabupaten Sukoharjo menunjukkan bahwa hasil uji chi square menunjukkan bahwa nilai $p=0,005<0,05$, maka Ha diterima dan dapat disimpulkan bahwa ada hubungan antara pengetahuan dengan kelengkapan imunisasi di wilayah kerja Puskesmas Kartasura Kabupaten Sukoharjo (Umaroh, 2014).

Menurut Azwar (2005) dalam Wawan (2011) menyatakan bahwa faktor yang mempengaruhi sikap antara lain pengalaman pribadi, pengaruh orang yang dianggap penting dan informasi dari media massa. Pengalaman pribadi dapat menjadi dasar pembentukan sikap, pengalaman pribadi haruslah meninggalkan kesan yang kuat.
Dari hasil penelitian yang telah dilakukan bahwa masih ada ibu yang mempunyai pengetahuan yang cukup dan kurang tentang imunisasi dasar pada bayi usia 0-9 bulan, serta masih ada ibu yang memiliki sikap yang tidak mendukung dalam pemberian imunisasi dasar lengkap pada bayi usia 0-9 bulan. Oleh karena itu perlu dilakukan kegiatan yang dapat meningkatkan pengetahuan ibu mengenai imunisasi dasar lengkap pada bayi usia 0-9 bulan, adapun kegiatan yang dapat meningkatkan pengetahuan ibu tentang imunisasi dasar pada bayi usia 0-9 bulan antara lain penyuluhan mengenai imunisasi dasar ada bayi 0-9 bulan, pembagian brosur atau leaflet, menempelkan poster, serta mengingatkan ibu untuk membaca buku Kesehatan Ibu dan Anak (KIA).

\section{Kesimpulan}

Berdasarkan hasil penelitian yang telah dilakukan, maka dapat disimpulkan bahwa tidak ada hubungan antara pengetahuan dan sikap ibu dalam pemberian imunisasi dasar lengkap pada ibu yang memiliki bayi 0-9 bulan. Saran untuk tempat penelitian adalah agar dapat melaksanakan kegiatan pendidikan kesehatan secara rutin khususnya mengenai imunisasi dasar lengkap agar dapat meningkatkan pengetahuan tentang imunisasi dasar lengkap sehingga dapat ikut mendukung program pemerintah mengenai imunisasi dasar lengkap yang wajib diberikan pada semua anak. 


\section{Daftar Pustaka}

Achmadi, Umar Fahmi. 2006. Imunisasi Mengapa Perlu?. Jakarta: Buku Kompas

Afrikayanti, Lilis, dkk. 2012. Hubungan Pengetahuan Ibu Tentang Imunisasi Dasar Dengan Kelengkapan Imunisasi Dasar Pada Bayi Usia 1 Tahun Di Puskesmas Depok I Sleman Yogyakarta. Karya Tulis Ilmiah. Universitas Respati, Yogyakarta (di publikasikan)

Arif, Nurhaeni. 2009. Panduan Ibu Cerdas ASI dan Tumbuh Kembang Bayi. Yogyakarta: Med Press

Arifianto. 2014. Pro Kontra Imunisasi. Bandung: Noura Books

Arikunto, Suharsimi. 2006. Prosedur Penelitian Suatu Pendekatan Praktik. Jakarta: Rineka Cipta

.2010. Prosedur Penelitian Suatu Pendekatan Praktik Jakarta: Rineka Cipta

2013. Prosedur Penelitian Suatu Pendekatan Praktik. Jakarta: Rineka Cipta

Bahiyatun. 2007. Buku Ajar Asuhan Kebidanan Nifas Normal. Jakarta: EGC

Budiman. 2013. Penelitian Kesehatan. Bandung: Refika Aditama

Cadwell, K dan Cindy, T. 2011. Buku Saku Manajemen Laktasi. Jakarta: EGC

Dinas Kesehatan KAL-BAR. 2011. Profil Kesehatan Provinsi 2011. http://www.depkes.go.id/resources/ download/profil/PROFIL-KES-PROV2011/P.PROV-KALBAR-2011.pdf, diakses: 28 Februari 2016

Dinas Kesehatan Provinsi Kalimantan Barat. 2012. Profil Kesehatan Provinsi Kalimantan Barat Tahun 2011. Pontianak
Fikawati, S, dkk. 2015. Gizi Ibu dan Bayi. Jakarta: Rajawali Pers

Hadinegoro, Sri Rezeki S. 2011. Panduan Imunisasi Anak. Edisi pertama tahun 2011. Satgas munisasi Ikatan Dokter Anak Indonesia. Jakarta: Badan Penerbit Ikatan Dokter Anak Indonesia

Hidayat, A. Aziz Alimul. 2009. Pengantar Ilmu Kesehatan Anak untuk Pendidikan Kesehatan. Jakarta: Salemba Medika

Hidayat, A. 2014. Metode Penelitian Kebidanan Kebidanan dan Teknik Analisis Data: Contoh Aplikasi Studi Kasus. Jakarta: Salemba Medika

Indrayani. 2011. Buku Ajar Asuhan Kehamilan. Jakarta: CV. Trans Info Media

Jad, Ahmad. 2014. Wanita dan Keluarga. Jakarta: Puspaswara

Kartika, V. 2016. Hubungan Dukungan Keluarga Dengan Keberhasilan ASI Eksklusif Pada Ibu Bekerja Di Wilayah Kerja Puskesmas Beringin Kabupaten Semarang. http://perpusnwu.web.id/karyailmiah/docu ment/4939.pdf, diakses: 28 Februari 2016

KBBI, 2008. Kamus Baku Bahasa Indonesia. http://jurnaloldi.or.id/public/kbbi.pdf, diakses: 03 Maret 2016

Kemenkes RI, 2015. Profil Kesehatan Indonesia 2015. http://www.depkes.go.id/resources/ download/pustadin/profil-kesehatanindonesia/profil-kes-indo-2015.pdf, diakses: 28 Februari 2016

Kristiyanasari, W. 2011. ASI menyusui dan Sadari. Yogyakarta: NuMed 
Kurniasih, D. 2015. Hubungan Pengetahuan Ibu Tentang Manajemen Laktasi Dengan Pemberian ASI Eksklusif Di Desa Bligo Kecamatan Ngluwar Kabupaten Magelang Jawa Tengah. http://opai.unisayogya.ac.id/37/1/NASKA HPUBLIKASIDIANKURNIASIH202014 10104045.pdf. diakses: 28 Februari 2016

Lisnawati, Lilis. 2014. Generasi Sehat Melalui Imunisasi. Jakarta: Trans Info Media

Lucky, Sri. 2015. Gambaran Dukungan Suami Dalam Pemberian ASI Eksklusif Di Posyandu Padasuka RW 06 dan RW Kelurahan Padasuka Kota Bandung. http://repository.upi.edu/15625/2/T

a.JKR.ch1.pdf, diakses: 28 Februari 2016

Lusiana, N, dkk. 2015. Buku Ajar: Metode Penelitian Kebidanan. Yogyakarta: CV. Budi Utama

Machfoedz, Irham. 2010. Metodologi Penelitian Kuantitatif dan Kualitatif Bidang Kesehatan, Keperawatan, Kebidanan, Kedokteran. Yogyakarta: Fitramaya 2011. Biostatistika, Bidang Kesehatan, Keperawatan, Kebidanan, Kedokteran. Yogyakarta: Fitramaya.

Marimbi, Hanum. 2010. Tumbuh Kembang, Status Gizi, \& Imunisasi Dasar Pada Balita. Yogyakarta: Nuha Medika

Marliandani, Y, dkk. 2015. Buku Ajar Asuhan Kebidanan Pada Masa Nifas dan Menyusui. Jakarta: Salemba Medika

Maryam, Siti. 2016. Gizi Dalam Kesehatan Reproduksi. Jakarta: Salemba Medika. Maryunani, A. 2012. IMD ASI Eksklusif dan Manajemen Laktasi. Jakarta: TIM

Maryunani, Anik. 2010. Ilmu Kesehatan Anak Dalam Kebidanan. Jakarta: Trans Info Media

Mubarak, Wahit Iqbal, Chayatin, Nurul, Rozikin, Khoirul. 2007. Promosi Kesehatan: Sebuah
Pengantar Proses Belajar Mengajar Dalam Pendidikan. Yogyakarta: Graha Ilmu

2012. Promosi Kesehatan. Yogyakarta: Graha Ilmu

Notoatmodjo, S. 2010. Promosi Kesehatan Teori dan Aplikasi. Jakarta: Rineka Cipta

. 2010. Metode Penelitian

Kesehatan. Jakarta: Rineka Cipta

2012. Metodelogi Penelitian

Kesehatan. Jakarta: Rineka Cipta

Nugroho, T. 2011. ASI dan Tumor Payudara. Yogyakarta: NuMed

Peraturan Menteri Kesehatan Republik Indonesia Nomor 42 Tahun 2013 Tentang Penyelenggaraan Imunisasi. Diakses Tanggal 28 Februari 2016. Pukul 14.56 WIB

Prasetyawati, Arsita Eka. 2012. Kesehatan Ibu Dan Anak (KIA) Dalam Millenium Development Goals (MDGs).

Yogyakarta: Nuha Medika

Prasetyo, Bambang. 2010. Metode Penelitian Kuantitatif Teori dan Aplikasi. Jakarta: Raja Grafindo Persada

Profil Puskesmas Alianyang Pontianak Kota Tahun 2014

Proverawati, Atikah. \& Andhini, Citra Setyo Dwi. 2010. Imunisasi dan Vaksinasi. Yogyakarta: Nuha Medika

Proverawati, A dan Eni R. 2010. Kapita Selekta ASI dan Menyusui. Yogyakarta: NuMed

Rahmawati, Adzaniyah Isyani. 2014. Faktor Yang Mempengaruhi Kelengkapan Imunisasi Dasar Di Kelurahan Krembangan Utara. Karya Tulis Ilmiah. Fakultas Kesehatan Masyarakat, Universitas Airlangga, Surabaya (di publikasikan) 
Rati, Angraeni Puspita. 2015. Analisis FaktorFaktor Yang Mempengaruhi Kelengkapan Imunisasi Dasar Lengkap Pada Batita Usia 9-24 Bulan Di Desa Pal Ix Kecamatan Sungai Kakap Kabupaten Kubu Raya. Portal Jurnal Ilmiah Universitas Tanjungpura. Volume 3, No 1. http://jurnal.untan.ac.id/index.php/jmkeper awatanFK/article/view/10 783/10306 diakses tanggal 21 April 2016 pukul 10.35 WIB

Ray, Agung. 2008. Audit Kinerja Pada Sektor Publik. Jakarta: Salemba Empat Rukiyah, Ai Y, dkk. 2011. Asuhan Kebidanan Nifas. Jakarta: TIM

Riset Kesehatan Dasar (RISKESDAS) 2013. Badan Penelitian Dan Pengembangan Kesehatan Kementerian Kesehatan RI. Diunduh dari http://www.depkes.go.id/resources/downl oad/general/Hasil\%20Riskesdas\%202013. pdf tanggal 27 Februari 2016, pukul 10.45 WIB

Roza, Selvina Elia, 2013. Hubungan Pengetahuan Dan Sikap Ibu Balita Dengan Cakupan Imunisasi Campak Dikelurahan Aur Kuning Wilayah Kerja Puskesmas Tigo Baleh Tahun 2013. Ejurnal STIKes Prima Nusantara. Volume 1, No 1, http://ejurnal.stikesprimanusantara.ac.id/in dex.php/JKSDIII/article/vie w/123 diakses tanggal 20 April 2016 pukul 16.45WIB

Rukiyah, Ai Yeyeh \& Yulianti, Lia. 2010. Asuhan Neonatus, Bayi Dan Anak Balita. Jakarta: Trans Info Media

Saleha, S. 2009. Asuhan Kebidanan Pada Masa Nifas. Jakarta: Salemba Medika

Sari, C M. 2012. Perbedaan Pola Pemberian ASI Dengan Keberhasilan ASI Eksklusif Di Posnyandu Ciputat Timur. http://eprints.undip.ac.id.cindymarth asari.pdf, diakses: 13 Mei 2016
Setiawan, Ari \& Saryono. 2011. Metodelogi Penelitian Kebidanan DIII, DIV, S1 dan S2. Yogyakarta: Nuha Medika

Siswanto, Susila, Suyanto. 2014. Metodelogi Penelitian Kesehatan Dan Kedokteran. Yogyakarta: Bursa Ilmu

Sudarti \& Khoirunnisa, Endang. 2010. Asuhan Kebidanan Neonatus, Bayi, Dan Anak Balita. Yogyakarta: Nuha Medika

Sugiyono. 2009. Statistik untuk Penelitian. Bandung: Alfabeta

2011. Statisitika Untuk Penelitian. Bandung: Alfabeta

Kuantitatif 2012. Metode Penelitian Bandung: Alfabeta

Sujarweni, W. 2014. Metode Penelitian Keperawatan. Yogyakarta: Gava Media Yuliarti, N. 2010. Keajaiban ASI Makanan Terbaik Untuk Kesehatan, Kecerdasan dan Kelincahan Sikecil. Yogyakarta: Andi

Supartini, Yupi. 2004. Buku Ajar Konsep Dasar Keperawatan Anak. Jakarta: Penerbit Buku Kedokteran EGC

Survey Demografi Kesehatan Indonesia (SDKI) 2012. Badan Penelitian Dan Pengembangan Kesehatan Kementerian Kesehatan RI. Diunduh dari http://chnrl.org/pelatihandemografi/SDKI-2012.pdf tanggal 28 Februari 2016, pukul 09.16 WIB

Suyanto. 2009. Riset Kebidanan. Yogyakarta: Mitra Cendikia

Umaroh, Siti. 2014. Hubungan Antara Pengetahuan Dan Sikap Ibu Dengan Kelengkapan Imunisasi Dasar Di Wilayah Kerja Puskesmas Kartasura Kabupaten Sukoharjo. Karya Tulis Ilmiah. Fakultas Kesehatan Masyarakat, Universitas Muhammadiyah, Surakarta (di publikasikan). 
Volume 6 Nomor 2 Tahun 2016

Wawan, A. 2010. Teori dan Pengukuran Pengetahuan, Sikap, dan Perilaku Manusia. Yogyakarta: Nuha Medika

Zakiyah, Anis. 2010. Hubungan Pengetahuan, Sikap Ibu Tentang Imunisasi Dan Dukungan Keluarga Dengan Kelengkapan Imunisasi Dpt Pada Bayi Umur 6-11bulan Di Desa Taman Gede Kecamatan Gemuh Kabupaten Kendal. Karya Tulis Ilmiah. Universitas Muhammadiyah, Semarang (di publikasikan)

Widyasari. 2016. Faktor-faktor yang Mempengaruhi Pemberian ASI Eksklusif Oleh Ibu Multipara Di Wilayah Puskesmas Ngresep Semarang. http://eprints.undip.ac.id/48259/3/BAB_1. pdf, diakses: 28 Februari 2016 